\title{
Hyperparasitism of Amyloodinium ocellatum (Dinoflagellida: Oodinidae) on Neobenedenia melleni (Monogenea: Capsalidae)
}

\author{
Angelo Colorni \\ Israel Oceanographic and Limnological Research, National Center for Mariculture, PO Box 1212, Eilat 88112, Israel
}

\begin{abstract}
During a simultaneous infestation of the gilthead sea bream Sparus aurata by Amyloodinium ocellatum (a blastodiniid dinoflagellate parasite on fish gills and skin) and Neobenedenia melleni (a capsalid monogenean parasite on fish skin), A. ocellatum was found to parasitize not only the fish but the monogenean parasites as well. This observation indicates that $A$. ocellatum is able to obtain the necessary nutrients for its development from a non-piscine host.
\end{abstract}

KEY WORDS: Hyperparasitism - Amyloodinium - Neobenedenia - Sparus aurata - Dinoflagellate - Capsalidae

Infestations of the gilt-head sea bream Sparus aurata L. by the gill/skin parasite Amyloodinium ocellatum Brown, 1931, a blastodiniid dinoflagellate, and Neobenedenia melleni (MacCallum, 1927) Yamaguti, 1963, a capsalid monogenean of the skin, are frequent occurrences in the facilities of the National Center for Mariculture (NCM) in Eilat, Red Sea, particularly during the summer. The 2 parasites have occasionally been seen sharing the same host during simultaneous infestations (Ellis \& Watanabe 1993, Colorni unpubl.). A. ocellatum is virtually non-specific in its fish host selection (Lawler 1980, Lauckner 1984) and N. melleni has been similarly reported to infest several species of commercial fish cultured in tropical seas (Gallet de Saint Aurin et al. 1990, Ellis \& Watanabe 1993). Previously known as Epibdella melleni, N. melleni has been reported to infest many species of tropical fish held in marine aquarium systems (Jahn \& Kuhn 1932, Nigrelli 1943). At NCM, N. melleni infested, besides $S$. aurata, the cichlid Oreochromis mossambicus, which was adapted to full strength seawater, and the dolphin fish Coryphaena hippurus.

The present report describes Neobenedenia melleni hyperparasitized by Amyloodinium ocellatum. The case was observed in July 1993 in a 170001 concrete tank in which over 100 adult Sparus aurata of about
$900 \mathrm{~g}$ were found to be heavily infested with A. ocellatum and lightly infested with $N$. melleni. Water temperature in the tank was $25^{\circ} \mathrm{C}$ and salinity $40 \%$.

Fresh mounts were examined and photographed using regular light microscopy. Infested worms were fixed in $10 \%$ neutral buffered formalin and embedded in methacrylate blocks according to standard procedures (Clark 1981). Sections (2 $\mu \mathrm{m}$ thick) were stained with methylene blue-basic fuchsin, periodic acid Schiff, hematoxylin-eosin and hematoxylin - Biebrich scarlet - fast green. The last stain is recommended for determining the effects of parasitic protozoans on tissues of invertebrates.

Amyloodinium ocellatum trophonts were firmly anchored to the dorsal sides of the opisthaptor (Fig. 1) and the body proper (Figs. 2 \& 3) of the worm. Up to a dozen were found on each worm. The trophonts were of various sizes $(35 \times 45$ to $64 \times 80 \mu \mathrm{m})$ which, had they been growing on fish epithelia, would correspond to about 2 to $4 \mathrm{~d}$ of 'age' (i.e. post-attachment).

From the characteristic digestive vacuoles and the fine, PAS positive, polysaccharide granules present in the cytoplasm of Amyloodinium ocellatum trophonts (Fig. 4), it is evident that the dinoflagellates actively fed on the worms. The damage the trophonts caused to their unusual host was difficult to evaluate, but seemed minimal and in any case limited to a focal structural disruption.

Amyloodinium ocellatum is a highly adaptable, cosmopolitan parasite (Nigrelli 1936, Lawler 1980, Paperna 1980, Barbaro \& Francescon 1985). Its tolerance to varying osmotic conditions (Paperna 1984) and lack of fastidiousness in its host range (Lawler 1980 , Lauckner 1984) have rendered the parasite amenable to propagation on fish cell cultures (Noga 1987).

Once detached from their fish host, whether spontaneously or as a result of having been dislodged, the trophonts sink to the bottom and transform into divid- 

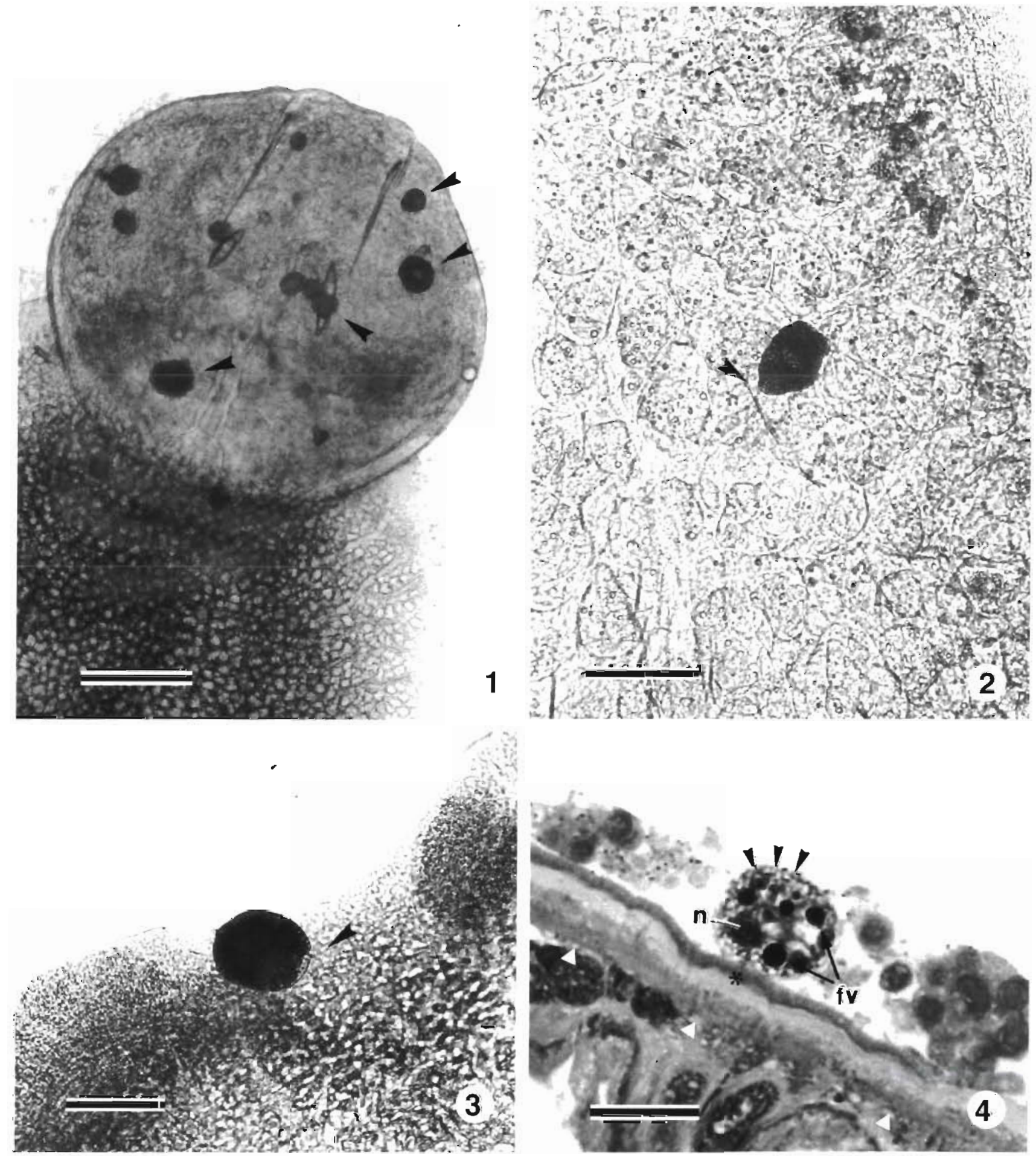

Figs 1 to 4 Amyloodinıum ocellatum infestıng Neobenedenıa melleni Fig. $1 . N$ melleni opisthaptor (dorsal side) infested with a number of $A$ ocellatum trophonts of different sizes (arrowed) Wet mount, unstamed Scale bar $=200 \mu m$. Figs. $2 \& 3$. A ocellatum trophonts attached to the dorsal side of $N$. mellens Arrow site of attachment Wet mount, unstained. Scale bars $=80 \mu m$ Fig. 4 A ocellatum trophont (n nucleus, fv food vacuoles, arrows polysacchande granules) parasitizing $N$. mellenI: *: site of attachment. White tnangles mark the border between tegumental layers (above) and the underlyng parenchyma of the monogenean Longitudinal section, hematoxylın-eosin stain Scale bar $=20 \mu \mathrm{m}$ 
ing tomonts (Paperna 1984). There is no evidence that an established trophont can detach from its original attachment site and re-attach to a different site. Evidently, Amyloodinium ocellatum attached to the monogenean at the stage of dinospore. Although the breaking down of $A$. ocellatum specificity for fish was probably determined by the unnatural conditions of intensive mariculture, it is nevertheless remarkable that $A$. ocellatum was able to obtain the necessary nutrients for its growth and development from a nonpiscine substrate.

The versatility and resilience of Amyloodinium ocellatum should be taken into account in the logistics for the control of this parasite, as attempts to eradicate it, for example by means of temporary fish exclusion (Bower 1987), may be frustrated by this organism's ability to exploit alternative host phyla.

Acknowledgements. I am indebted to Prof. I. Paperna of the Dept of Animal Sciences, Faculty of Agriculture, Hebrew University of Jerusalem, Rehovot, for positive identification of Neobenedenia melleni and critical review of the manuscript. The techical assistance of E. Berger and H. Kruglish is gratefully acknowledged.

\section{LITERATURE CITED}

Barbaro, A., Francescon, A. (1985). Parassitosi da Amyloodinium ocellatum (Dinophyceae) su larve di Sparus aurata allevate in un impianto di riproduzione artificiale. CEbalia XI-2: 745-752

Bower, C. E. (1987). Update on Amyloodinium ocellatum. Sea Scope, Aquarium Systems, Inc., Mentor, $\mathrm{OH}$

Clark, G. (1981). Staining procedures. Williams and Wilkins, Baltimore

Responsible Subject Editor: A. K. Sparks, Seattle, Washington, USA
Ellis, E. P., Watanabe, W. O. (1993). The effects of hyposalinity on eggs, juveniles and adults of the marine monogenean, Neobenedenia melleni. Treatment of ectoparasitosis in seawater-cultured tilapia. Aquaculture 117: $15-27$

Gallet de Saint Aurin, D., Raymond, J. C., Vianas, V. (1990). Marine finfish pathology: specific problems and research in the French West Indies. In: Barret, J., Calvas, J., Cuzon, G., Fuchs, J., Weppe, M. (ed.) Advances in tropical aquaculture, Tahiti, French Polynesia, Feb. 20-March 4, 1989. AQUACOP, Institut Français de Recherche pour l'Exploitation de la Mer (IFREMER), Actes de Colloque No. 9. IFREMER, Plouzané, p. 143-160

Jahn, T L., Kuhn, L. R. (1932). The life history of Epibdella melleni MacCallum, 1927, a monogenetic trematode parasitic on marine fishes. Biol. Bull. 62: 89-111

Lauckner, G. (1984). Diseases caused by protophytans (algae). In: Kinne, O. (ed.) Diseases of marine animals, Vol. IV, Part 1, Pisces. Biologische Anstalt Helgoland, Hamburg, p. 169-179

Lawler, A. R. (1980). Studies on Amyloodinium ocellatum (Dinoflagellata) in Mississippi sound: natural and experimental hosts. Gulf Res. Rep. 6(4): 403-413

Nigrelli, R. F. (1936). The morphology, cytology and life history of Oodinium ocellatum Brown, a dinoflagellate parasite on marine fishes. Zoologica, N.Y. 21: 129-164

Nigrelli, R. F. (1943). Causes of diseases and death of fishes in captivity. Zoologica, N.Y. 28: 203-216

Noga, E. J. (1987). Propagation in cell culture of the dinoflagellate Amyloodinium, an ectoparasite of marine fishes. Science 236: 1302-1304

Paperna, I. (1980). Amyloodinium ocellatum (Brown, 1931) (Dinoflagellida) infestations in cultured marine fish at Eilat, Red Sea: epizootiology and pathology. J. Fish Dis. 3: $363-372$

Paperna, l. (1984). Reproduction cycle and tolerance to temperature and salinity of Amyloodinium ocellatum (Brown, 1931) (Dinoflagellida). Annls Parasit. hum. comp. 59(1): $7-30$

Manuscript first received: November 30, 1993

Revised version accepted: March 18, 1994 